\title{
Simulation of mussel Mytilus galloprovincialis growth with a dynamic energy budget model in Maliakos and Thermaikos Gulfs (Eastern Mediterranean)
}

\author{
Yannis Hatzonikolakis, ${ }^{1,2}$, Kostas Tsiaras $^{2}$, John A. Theodorou ${ }^{3}$, George Petihakis ${ }^{4}$, \\ Sarantis Sofianos ${ }^{1}$, George Triantafyllou ${ }^{2, *}$ \\ ${ }^{1}$ Department of Environmental Physics, University of Athens, 15784 Athens, Greece \\ ${ }^{2}$ Hellenic Centre for Marine Research (HCMR), Athens-Sounio Avenue, Mavro Lithari, 19013 Anavyssos, Greece \\ ${ }^{3}$ Department of Fisheries and Aquaculture Technology, Technological Educational Institute of Western Greece, Nea Ktiria, \\ Mesolonghi 30200, Greece \\ ${ }^{4}$ Hellenic Centre for Marine Research (HCMR), 71003 Heraklion, Greece
}

\begin{abstract}
A dynamic energy budget (DEB) model was developed to investigate the growth and reproduction of cultured bivalve species raised under different environmental conditions (varying phytoplankton carbon biomass [Phyto-C], particulate organic carbon [POC] and temperature) and tuned against field data for Mytilus galloprovincialis from the Maliakos and Thermaikos Gulfs (Aegean Sea, Greece). Values of most DEB model parameters were adopted from the literature, while half saturation constant $\left(X_{\mathrm{k}}\right)$ and initial values of energy reserves $(E)$ and reproductive buffer $(R)$ were calibrated. Different values have been found for $X_{\mathrm{k}}$ in the 2 areas (Maliakos: $X_{\mathrm{k}}=$ $36 \mathrm{mg} \mathrm{C} \mathrm{m}^{-3}$; Thermaikos: $X_{\mathrm{k}}=28 \mathrm{mg} \mathrm{C} \mathrm{m}^{-3}$ ), suggesting that $X_{\mathrm{k}}$ should be treated as a site-specific parameter. Food density $(X)$ was adapted to include not only Phyto-C but also POC in the diet of M. galloprovincialis and only when Phyto-C density was low compared to POC density. Results showed a small contribution of POC during spring in the Maliakos Gulf and almost none at Thermaikos Gulf. The simulated mussel growth showed good agreement with field data. Sensitivity tests on the calibrated parameters $\left(E, R\right.$ and $\left.X_{\mathrm{k}}\right)$ were performed to investigate model uncertainty. The standard deviation of simulations with perturbed parameter/initial values remained relatively small and appeared to increase as the modeled mussel grew, in agreement with observations.
\end{abstract}

KEY WORDS: Dynamic energy budget - DEB model - Mussel culture $\cdot$ Mytilus galloprovincialis Growth $\cdot$ Eastern Mediterranean $\cdot$ Uncertainty $\cdot$ Ensemble forecasting

\section{INTRODUCTION}

According to the Food and Agriculture Organization of the United Nations (FAO), the world's population will reach 8 billion people in 2030. This increase is not reflected in wild fisheries or oyster production, which have been practically steady since 1989 . On the other hand, world aquaculture production has shown an enormous growth in the last 3 decades, increasing from $14 \%$ of total seafood production in 1988 to $44.1 \%$ in 2014 (FAO 2016). A significant amount of

*Corresponding author: gt@hcmr.gr this aquaculture production comes from shellfish farms. For example, in Europe in 2009, $57 \%$ of total aquaculture production came from mussel, clam and oyster farming (Eurostat 2016). Considering that shellfish farming takes place in coastal zones which are affected both by anthropogenic pressures and climate change, it is important to analyze and understand the processes that affect production. Among the most important cultured bivalve species is the Mediterranean mussel Mytilus galloprovincialis, which has significant global production (116262 metric tonnes [t] in 2014

() The authors 2017. Open Access under Creative Commons by Attribution Licence. Use, distribution and reproduction are unrestricted. Authors and original publication must be credited. 
according to $\mathrm{FAO}^{\mathbf{1}}$ ) and is mainly cultured on the northern shores of the Mediterranean Sea (Rodrigues et al. 2015). Greece contributes significantly to Mediterranean M. galloprovincialis farming, with an estimated maximum farming carrying capacity up to 35000 or 40000 t gross weight (although production levels are currently lower: $18000 \mathrm{t}$ in 2014; FGM 2015). Because of the overall oligotrophic characteristics of the Mediterranean, major farming areas are only found close to estuarine systems. In Greece, these are mainly located in the northern part of the country where major rivers discharge (Theodorou et al. 2011, 2015a), and are more scattered in other areas of continental Greece (Fig. 1).

In the present study, the growth of M. galloprovincialis in the Maliakos and Thermaikos Gulfs was investigated. A model describing the growth of M. galloprovincialis was developed based on dynamic energy budget (DEB) theory (Kooijman 1986, 2000). The model simulates the growth of an individual cultured mussel, assuming that the simulated individual represents the average state of the farm's population. DEB models have been applied successfully for several bivalve species (Casas \& Bacher 2006, Pouvreau et al. 2006, Zaldívar 2008, Bourlès et al. 2009, Troost et

${ }^{1}$ China and Spain mussel production is not reported as Mytilus galloprovincialis production by FAO

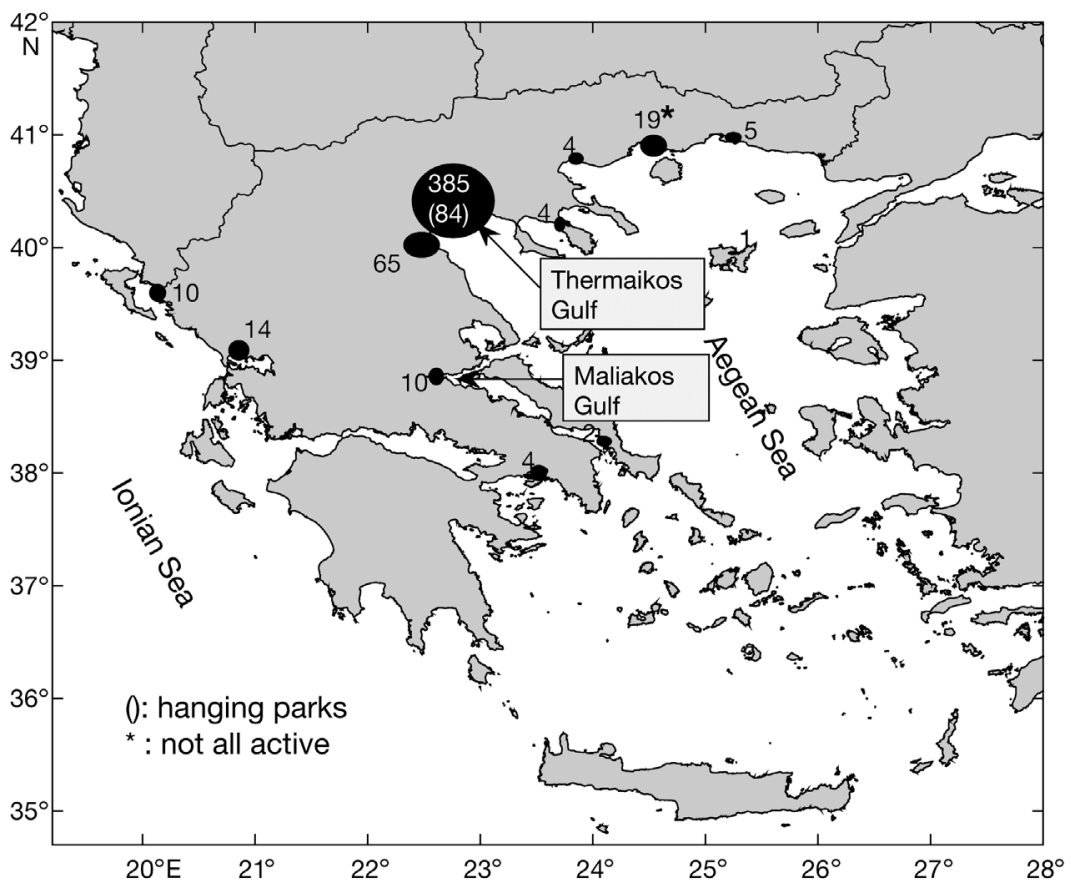

Fig. 1. Mussel farms (black circles) in Greece, Eastern Mediterranean. Numbers of floating longlines (no. of hanging parks in brackets) in the area are indicated. (*) Licensed but not yet active longlines. Study areas (Thermaikos and Maliakos Gulfs) are indicated (adapted from Theodorou et al. 2011, 2015a) al. 2010, Handa et al. 2011, Thomas et al. 2011, Wijsman \& Smaal 2011, Sarà et al. 2012, among others).

DEB models show important benefits in describing the growth of an individual organism and have the powerful aspect of being generic: DEB theory assumptions represent physiological processes that are common among different species, with their differences reflected only in the values of the parameters. Moreover, DEB models can be used as a basis for modeling other processes, e.g. concentrations of contaminants in an individual (Zaldívar 2008) or bioaccumulation of trace metals (Casas \& Bacher 2006). Larsen et al. (2014) compared the results of bio-energetic growth (BEG), scope for growth (SFG) and DEB models on growth data of blue mussels from Danish waters, and concluded that the DEB model provided the best results and predictions regarding mussel somatic growth. Brigolin et al. (2009) chose a model based on the dynamic estimation of SFG as being more appropriate to study nutrient, carbon and phosphorus fluxes related to ingestion and the production of feces and pseudofeces in M. galloprovincialis. In their study, they also compared the results between their model and the DEB model produced by Casas \& Bacher (2006), concluding that both models can give good simulations regarding the somatic growth of $M$. galloprovincialis.

The primary objective of this work was to develop a model describing the growth and reproduction of the Mediterranean mussel M. galloprovincialis that can be used to investigate processes affecting production on shellfish farms, offering a useful tool for the study of mussel farming in the Maliakos and Thermaikos Gulfs and estimating the carrying capacity of the study areas.

\section{MATERIALS AND METHODS}

\section{Study area and mussel growth data}

Maliakos Gulf is a semi-enclosed, shallow (14 m mean depth) estuarine embayment in the central western part of the Aegean Sea which covers a total surface of $110 \mathrm{~km}^{2}$. It receives fresh water discharge from the Spercheios River at an average rate of $68 \mathrm{~m}^{3} \mathrm{~s}^{-1}$; there is also some inflow of more saline water from the N. Evoikos Gulf through an anti-clockwise circulation in the 
northern part of the gulf (Christou et al. 1995). Mussel farming was established in late 1980s, and today there are 10 farms with an estimated total annual production of around 1500 to $1700 \mathrm{t} \mathrm{yr}^{-1}$ (Dimitriou et al. 2015, Theodorou et al. 2015b).

Monthly mussel growth data (i.e. fresh tissue mass [g] and shell length [cm]) were derived from a farm (CalypsoSeafood/Aqua-Consulting) in the area of Molos (Southern Maliakos). Specifically, 3 pergolaries (mussel 'socks' made of plastic cylindrical nets) $3 \mathrm{~m}$ in length were filled with mussel seed $(\mathrm{n}=30)$ of average $( \pm \mathrm{SD})$ length $(3.68 \pm 0.53 \mathrm{~cm})$ and weight $(1.43 \pm 0.21 \mathrm{~g})$. The pergolaries were attached to a 'mother' longline rope at the edge of the farm in September 2004. To estimate animal growth, on a monthly basis 30 to 40 mussels were randomly collected from this batch for morphometric analysis during the period from October 2004 to June 2005.

Thermaikos Gulf is a semi-enclosed basin with a total surface area of $5100 \mathrm{~km}^{2}$, located in the northwest Aegean. Depth varies from 10 to $75 \mathrm{~m}$ and the tidal range is $0.25 \mathrm{~m}$. The inner Thermaikos Gulf is one of the few areas in Greece that can be characterized as eutrophic (Pagou 2005, Papakonstantinou et al. 2007), and contains one of the most extensive and productive mussel aquacultures, reaching $90 \%$ of total production in Greece (Konstantinou et al. 2015).

Mussel growth data, provided by Kravva (2000) from the coastal area of Chalastra, were used for tuning the Thermaikos Gulf model. This area is influenced by 2 of the most important rivers (Axios, Aliakmon) in the northern Aegean. It receives significant inputs of particulate matter and dissolved constituents (Price et al. 2005), creating favorable conditions for phytoplankton growth and thus is an ideal area for the cultivation of mussels.

\section{Environmental data}

Near-surface temperature and phytoplankton carbon biomass (Phyto-C) data (Fig. 2) were used as forcing functions for the DEB mussel model implementations in the Maliakos and Thermaikos Gulfs.

Data provided for Maliakos (August 2004 to August 2005) are outcomes of the Project ARCHIMIDES I -EPEAEK II-EU (contract no. 10012-00004) 'Environmental Interactions of the Mussel farming' (20042007). Relevant data used in the present study are from the deliverables of this effort presented in Theodorou et al. (2006a,b 2007) and Kakali et al. (2006). Monthly data samples at 4 depths $(0.5,2,3$ and $6 \mathrm{~m}$ ) were used to calculate mean near-surface chlorophyll a (chl a) and temperature. Phyto-C was obtained from chl a data, assuming a constant carbon:chl a ratio (50:1) that can be considered as a mean value of ratio's seasonal variability (Malone \& Chervin 1979, Geider \& Piatt 1986, Kormas et al. 2002). These datasets were used to force the model, and their values at each model time step were obtained by linear interpolation from the monthly data. Particulate organic carbon (POC) used in model simulations was obtained from Kormas et al. (2002).

In Thermaikos Gulf, input data (temperature, PhytoC, POC) for the period during which mussel growth data were available (May 1995 to July 1996) were obtained from a 3-dimensional (3-D) hydrodynamic/biochemical long-term model simulation over the 1980 to 2000 period (Tsiaras et al. 2014). The hydrodynamic model was based on the Princeton Ocean Model (POM; Blumberg \& Mellor 1983) while the biochemical model was based on the European Regional Seas Ecosystem Model (ERSEM; Baretta et al. 1995). The 3D model results were validated against available SeaWiFS chl $a$ and in situ data (Tsiaras et al. 2014).

The 2 coastal environments show some differences, mostly related to the maximum values and variability of Phyto-C. In Maliakos Gulf, Phyto-C reaches its highest value in winter $\left(277 \mathrm{mg} \mathrm{C} \mathrm{m}^{-3}\right)$, when the phytoplankton bloom takes place. This bloom is attributed to the supply of nutrients from Sperchios River in the early winter and is characterized by rapid sedimentation of phytoplankton cells to the shallow seafloor (Kormas et al. 1998). In Thermaikos Gulf (Chalastra), Phyto-C peaks in late April with a value of $138 \mathrm{mg} \mathrm{C} \mathrm{m}{ }^{-3}$. Although Phyto-C in Maliakos Gulf exhibits a significantly higher peak compared to Thermaikos, the annual mean values are similar in the 2 areas (Maliakos: $94.5 \mathrm{mg} \mathrm{C} \mathrm{m}^{-3}$; Thermaikos: $90 \mathrm{mg} \mathrm{C} \mathrm{m}^{-3}$ ). In Maliakos Gulf, Phyto-C was high throughout August 2004 to February 2005, but afterward decreased to very low levels between March 2005 and August 2005. Phyto-C in Thermaikos Gulf showed more moderate fluctuations. This can be attributed to the fact that the 3-D hydrodynamic/ biochemical model of Thermaikos Gulf adopts a climatologic seasonal variability for river discharge and therefore cannot capture high-frequency variability.

\section{DEB model}

Description of the DEB mussel model

The basic assumption of a DEB model is that the assimilated food first enters a reserve pool and then is 


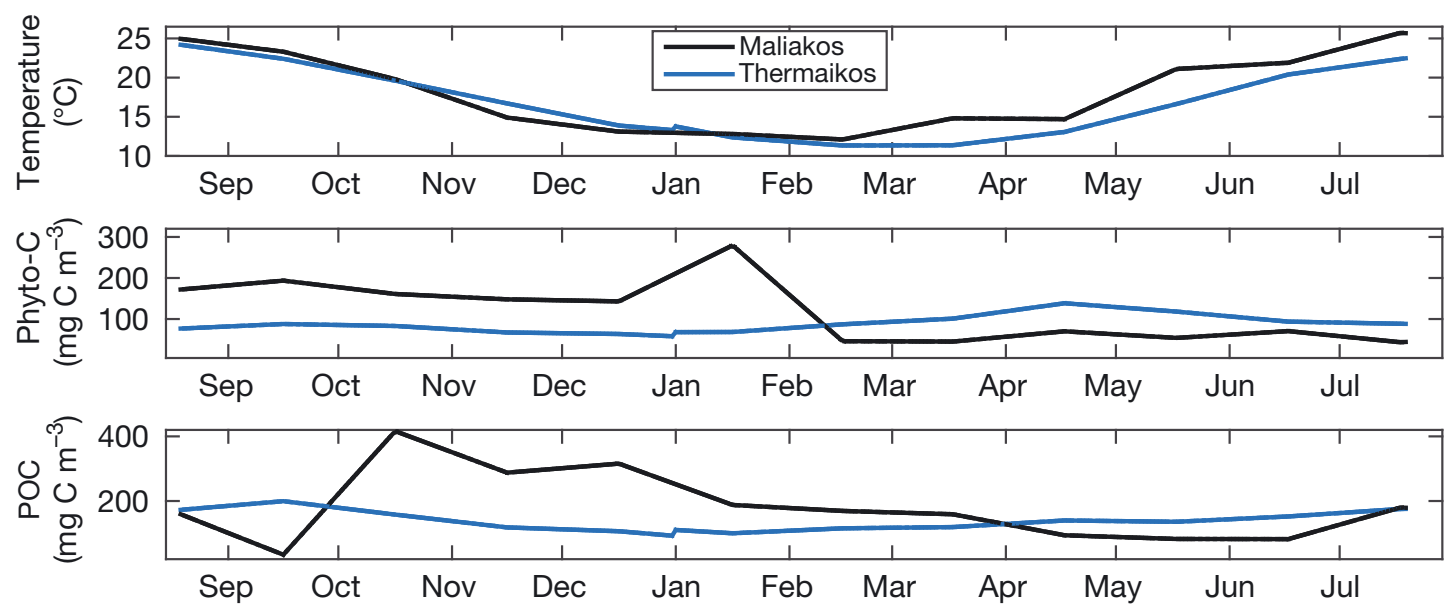

Fig. 2. Environmental data used for the forcing of the dynamic energy budget model in the Maliakos (black line) and Thermaikos (blue line) Gulf simulations, showing temperature (top), phytoplankton carbon biomass (middle), and particulate organic carbon (bottom)

allocated between the other compartments: a fixed part, $\kappa$, is spent on somatic maintenance and growth, while the remaining, $1-\kappa$, on maturity maintenance and reproduction. This rule is known as the $\kappa$-rule. The individual is characterized by 3 state variables: structural volume $V\left(\mathrm{~cm}^{3}\right)$, energy reserves $E$ (joules) and energy allocated to development and reproduction $R$ (joules), while the environment of the individual is described by food density and temperature. All model equations describing the time evolution of feeding, maintenance, growth, development and reproduction are shown in Table 1; descriptions of model variables are provided in Table 2 . The interested reader may refer to Zaldívar (2008) and Casas \& Bacher (2006) for a full description of the model equations.

\section{Parameter values}

Most of the model parameters used in the present study for Mytilus galloprovincialis are adapted from those estimated by Van der Veer et al. (2006) for the blue mussel $M$. edulis L. in the northeast Atlantic (see Table 3 for exceptions). The 2 mussel species are closely related and are very similar 'with no single morphological or genetic character being clearly diagnostic' (Gosling 1984, p. 554). Preliminary experimentation showed that this specific parameterization resulted in good agreement of M. galloprovincialis model-simulated growth with observations. A similar approach was used by Casas \& Bacher (2006) for $M$. galloprovincialis along the French Mediterranean shoreline. The half-saturation coefficient $\left(X_{\mathrm{k}}\right)$ was tuned in the current study in order to obtain a better fit of model-simulated growth with observations. Widdows et al. (1984) and later Camacho et al. (1995) showed that the differences in physiological responses among populations, which are mainly

Table 1. Dynamic energy budget model: equations. See Table 2 for model variables, Table 3 for parameters and Table 4 for initial values

$\frac{d E}{d t}=\dot{p}_{\mathrm{a}}-\dot{p}_{\mathrm{c}}$
$\frac{d V}{d t}=\frac{\kappa \cdot \dot{p}_{\mathrm{c}}-\left[\dot{p}_{\mathrm{M}}\right] \cdot V}{\left[E_{\mathrm{g}}\right]}$
$\frac{d R}{d t}=(1-k) \cdot \dot{p}_{\mathrm{c}}-\left[\frac{1-\kappa}{\kappa}\right] \cdot \min \left(V, V_{\mathrm{p}}\right) \cdot\left[\dot{p}_{\mathrm{M}}\right]$
$\dot{p}_{\mathrm{a}}=\left\{\dot{p}_{\mathrm{Am}}\right\} \cdot f \cdot k(T) \cdot V^{2 / 3}$
$f=\frac{X}{X+X_{\mathrm{k}}}$
$\dot{p}_{\mathrm{c}}=\frac{[E]}{\left[E_{\mathrm{g}}\right]+\kappa \cdot[E]} \cdot\left(\frac{\left[E_{\mathrm{g}}\right] \cdot\left\{\dot{p}_{\mathrm{AM}}\right\} \cdot k(T) \cdot V^{2 / 3}}{\left[E_{\mathrm{m}}\right]}+\left[\dot{p}_{\mathrm{M}}\right] \cdot V\right)$
$[E]=\frac{E}{V}$
$\left[\dot{p}_{\mathrm{M}}\right]=k(T) \cdot\left[\dot{p}_{\mathrm{M}}\right]_{\mathrm{m}}$
$k(T)=\frac{\exp \left(\frac{T_{\mathrm{A}}}{T_{\mathrm{I}}}-\frac{T_{\mathrm{A}}}{T}\right)}{1+\exp \left(\frac{T_{\mathrm{AL}}}{T}-\frac{T_{\mathrm{A}}}{T_{\mathrm{L}}}\right)+\exp \left(\frac{T_{\mathrm{AH}}}{T_{\mathrm{H}}}-\frac{T_{\mathrm{AH}}}{T}\right)}$
$L=\frac{V^{1 / 3}}{\delta_{\mathrm{m}}}$
$W=d \cdot\left(V+\frac{E}{\left[E_{\mathrm{g}}\right]}\right)+\frac{R}{\mu_{\mathrm{E}}}$


Table 2. Dynamic energy budget model: variables

\begin{tabular}{|lll|}
\hline Variable & Description & Units \\
\hline$V$ & Structural volume & $\mathrm{cm}^{3}$ \\
$E$ & Energy reserves & $\mathrm{J}$ \\
$R$ & Energy allocated to development & $\mathrm{J}$ \\
& and reproduction & $\mathrm{J} \mathrm{d}^{-1}$ \\
$\dot{p}_{\mathrm{a}}$ & Assimilation energy rate & $\mathrm{J} \mathrm{d}^{-1}$ \\
$\dot{p}_{\mathrm{c}}$ & Energy utilization rate & - \\
$f$ & Functional response function & $\mathrm{mg} \mathrm{C} \mathrm{m}^{-3}$ \\
$X$ & Food density & $\mathrm{J} \mathrm{cm}^{-3} \mathrm{~d}^{-1}$ \\
{$\left[\dot{p}_{\mathrm{M}}\right]$} & Maintenance costs & $\mathrm{K}$ \\
$T$ & Temperature & - \\
$k(T)$ & Temperature dependence & $\mathrm{cm}^{2}$ \\
$L$ & Shell length & $\mathrm{g}$ \\
$W$ & Fresh tissue mass & \\
\hline
\end{tabular}

responsible for differences in growth rate, are mainly the result of environmental conditions and to a lesser extent, genetic differences. Therefore, a good modeling approach would be to capture the differences in physiological responses among the 2 similar species and populations (Hilbish et al. 1994, Fly \& Hilbish 2013) by the site-specific parameter, $X_{\mathrm{k}}$ (Troost et. al. 2010). $X_{\mathrm{k}}$ is the amount of food (PhytoC, POC) where food uptake is at half its maximum value (see 'Food density' below) and may be considered representative of the environment to which the organism has adapted. A higher value of $X_{\mathrm{k}}$ is thus expected in more productive environments, such as the French Mediterranean shoreline as in Casas \& Bacher (2006) $\left(X_{\mathrm{k}}=3.88 \mu \mathrm{g} \mathrm{l}^{-1} ; \sim 194 \mathrm{mg} \mathrm{C} \mathrm{m}^{-3}\right)$ and a lower value in less productive areas, such as the Aegean coastal areas. Specific density $(d)$ was set to $1 \mathrm{~g} \mathrm{~cm}^{-3}$ as suggested by Kooijman (2000). The values of all DEB model parameters used are summarized in Table 3.

\section{Initial values}

The initial values used for each simulation run are shown in Table 4 . For both study areas, the initial value of shell length $(L)$ was set from the field data, while initial $V$ was calculated from Eq. (10) (see Table 1). For the Thermaikos simulation, initial $R$ was chosen to be 0 ; the initial mussel body volume, $V$, indicates that the individual is in the juvenile phase $(V<$ $V_{\mathrm{p}}$ see Table 3) and thus it was assumed that the animal has no energy allocated for reproduction yet, following the same approach as Thomas et al. (2011). In Maliakos Gulf, the initial $V$, obtained from the field data, suggests that the individual is mature and thus some energy has to be allocated for reproduction $(R)$. In the absence of available data, a model simulation initialized as in the Thermaikos Gulf $\left(V<V_{\mathrm{p}}\right.$ and $R=$ 0 ) was used to estimate the initial $R$ at the observed mussel length $(L=3.68 \mathrm{~cm})$ and weight $(W=1.43 \mathrm{~g})$ at Maliakos. For both study areas, the initial value of $E$ was calibrated (Table 4), so that the computed initial $W$ (Eq. 11) shows the best fit with field data. Regarding initial allocation between $E$ and $R$, Rosland et al. (2009) performed sensitivity experiments and demonstrated that it has little impact on the results.

Table 3. Dynamic energy budget model: parameters

\begin{tabular}{|lclcl|}
\hline Parameter & Units & Description & Value & Reference \\
\hline$\left\{\dot{p}_{\mathrm{Am}}\right\}$ & $\mathrm{J} \mathrm{cm}^{-2} \mathrm{~d}^{-1}$ & Maximum surface area-specific assimilation rate & 147.6 & Van der Veer et al. (2006) \\
$X_{\mathrm{k}}$ & $\mathrm{mg} \mathrm{C} \mathrm{m}^{-3}$ & Half saturation coefficient & Calibrated & - \\
$T_{\mathrm{A}}$ & $\mathrm{K}$ & Arrhenius temperature & 5800 & Van der Veer et al. (2006) \\
$T_{\mathrm{I}}$ & $\mathrm{K}$ & Reference temperature & 293 & Van der Veer et al. (2006) \\
$T_{\mathrm{L}}$ & $\mathrm{K}$ & Lower boundary of tolerance rate & 275 & Van der Veer et al. (2006) \\
$T_{\mathrm{H}}$ & $\mathrm{K}$ & Upper boundary of tolerance rate & 296 & Van der Veer et al. (2006) \\
$T_{\mathrm{AL}}$ & $\mathrm{K}$ & Rate of decrease of lower boundary & 45430 & Van der Veer et al. (2006) \\
$T_{\mathrm{AH}}$ & $\mathrm{K}$ & Rate of decrease of upper boundary & 31376 & Van der Veer et al. (2006) \\
{$\left[\dot{p}_{\mathrm{M}}\right]_{\mathrm{m}}$} & $\mathrm{J} \mathrm{cm}^{-3} \mathrm{~d}^{-1}$ & Volume specific maintenance costs & 24 & Van der Veer et al. (2006) \\
{$\left[E_{\mathrm{G}}\right]$} & $\mathrm{J} \mathrm{cm}^{-3}$ & Volume specific costs of growth & 1900 & Van der Veer et al. (2006) \\
{$\left[E_{\mathrm{m}}\right]$} & $\mathrm{J} \mathrm{cm}^{-3}$ & Maximum energy density & 2190 & Van der Veer et al. (2006) \\
$\kappa$ & - & Fraction of utilized energy spent on maintenance/growth & 0.7 & Van der Veer et al. (2006) \\
$V_{\mathrm{p}}$ & $\mathrm{cm}^{3}$ & Volume at start of reproductive stage & 0.06 & Van der Veer et al. (2006) \\
$\delta_{\mathrm{m}}$ & - & Shape coefficient & 0.25 & Casas \& Bacher (2006) \\
$d$ & $\mathrm{~g} \mathrm{~cm}^{-3}$ & Specific density & 1.0 & Kooijman (2000) \\
$\mu_{\mathrm{E}}$ & $\mathrm{J} \mathrm{g}^{-1}$ & Energy content of reserves & 6750 & Casas \& Bacher (2006) \\
\hline
\end{tabular}


Table 4. Dynamic energy budget model: initial values. $L$ : shell length; $W$ : fresh tissue mass; $V$ : structural volume; $E$ : energy reserves; $R$ : energy allocated to development and reproduction

\begin{tabular}{|cccc|}
\hline \multicolumn{2}{c}{ Maliakos Gulf } & \multicolumn{2}{c|}{ Thermaikos Gulf } \\
Variable & Value & Variable & Value \\
& & & \\
\hline \multirow{2}{*}{ Start date } & 28 Sep 2004 & Start date & 15 May 1995 \\
$L$ & $3.68 \mathrm{~cm}$ & $L$ & $0.84 \mathrm{~cm}$ \\
$W$ & $1.43 \mathrm{~g}$ & $W$ & $0.054 \mathrm{~g}$ \\
$V$ & $0.7787 \mathrm{~cm}^{3}$ & $V$ & $0.0093 \mathrm{~cm}^{3}$ \\
$E$ & $700 \mathrm{~J}$ & $E$ & $350 \mathrm{~J}$ \\
$R$ & $300 \mathrm{~J}$ & $R$ & $0 \mathrm{~J}$ \\
\hline
\end{tabular}

This conclusion has been verified with the method of Rosland et al. (2009) on preliminary tests. Allocating all initial energy to $E$ increased final $L$ by $0.87 \%$ and final $W$ by $2.84 \%$. Allocating all initial energy to $R$ decreased final $L$ by $2.18 \%$ and $W$ by $6.32 \%$.

\section{Simulation of reproduction}

To simulate the loss of mussel weight at spawning (Van Haren et al. 1994), the buffer $R$ was completely emptied $(R=0)$ on the spawning day, which was set at the time of the year when the field data and literature indicate that spawning events occur. The same method was applied by Handa et al. (2011) and Zaldívar (2008). Spawning events for M. galloprovincialis in Maliakos and Thermaikos Gulfs occur between December and March (Fasoulas \& Fantidou 2008, Theodorou et al. 2011). Thus, for the simulated mussel individual the spawning day was set at about the middle of the spawning season.

\section{Food density}

The relation between food uptake and food density is described by a Holling Type II (Holling 1959) functional response, $f$ (Eq. 5), which can vary between 0 and 1. As a first approach, only Phyto-C was considered in the food density $(X): X=[$ Phyto-C]. As a second method, the functional response was adjusted to include not only Phyto-C but also POC in the simulated mussel diet. In this case, the food density $X$ is given by:

$$
X=\frac{a \cdot[\text { Phyto }-\mathrm{C}]+b \cdot[\mathrm{POC}]}{a_{\mathrm{f}}+b_{\mathrm{f}}}
$$

where $a$ and $b$ are given by:

$$
\begin{gathered}
a=a_{\mathrm{f}} \cdot \frac{[\text { Phyto }-\mathrm{C}]}{[\text { Phyto }-\mathrm{C}]+X_{\mathrm{k}}} \\
b=b_{\mathrm{f}} \cdot \frac{[\mathrm{POC}]}{[\text { POC }]+X_{\mathrm{k}}}
\end{gathered}
$$

where [Phyto-C] is the density of available Phyto-C and $[\mathrm{POC}]$ is the density of available POC. Parameters $a_{\mathrm{f}}$ and $b_{\mathrm{f}}$ describe the mussels' relative preference for Phyto-C and POC, which is related to food quality. Troost et al. (2010) investigated the importance of detritus as a food source between different shellfish species and concluded that the contribution of detritus to shellfish's diet might differ among different environments. For example, cockles prefer phytoplankton as a food source but in those areas where phytoplankton concentrations are low, cockles can also assimilate detritus (Troost et al. 2010). To simulate this behavior, variable preference weights $(a, b)$ were adopted, depending on the availability of food resources in terms of Phyto-C and POC, as given by Eqs. (13) \& (14). In this way, the contribution of POC will be significant only when Phyto-C is low compared to POC density. The seasonal contribution of POC for M. galloprovincialis is discussed below. Parameters $a_{\mathrm{f}}$ and $b_{\mathrm{f}}$ were determined by calibration: $a_{\mathrm{f}}=0.55$, and $b_{\mathrm{f}}=0.45$ (see 'Discussion' for more details regarding these values).

\section{Simulation of starvation}

Following Rosland et al. (2009) and Handa et al. (2011), when the growth rate according to Eq. (2) is negative, it is assumed that the energy utilization rate is not enough to cover somatic maintenance. In this case, the mussel is assumed to be in a starvation state and stops growing ( $\mathrm{d} V / \mathrm{d} t$ is set to 0 ). Energy is also withdrawn from the reproductive buffer to cover the maintenance deficit, following Handa et al. (2011); thus the reproduction equation changes to:

$$
\frac{\mathrm{d} R}{\mathrm{~d} t}=\kappa \cdot \dot{p}_{\mathrm{c}}-\dot{p}_{\mathrm{M}}
$$

\section{RESULTS}

\section{Model simulation}

Simulations of the growth of Mytilus galloprovincialis for the same period as the experimental data were performed first with food density $X=$ [Phyto-C]. Results are shown in Fig. 3 for Maliakos Gulf and Fig. 4 for Thermaikos Gulf. $X_{\mathrm{k}}$ was tuned to different 

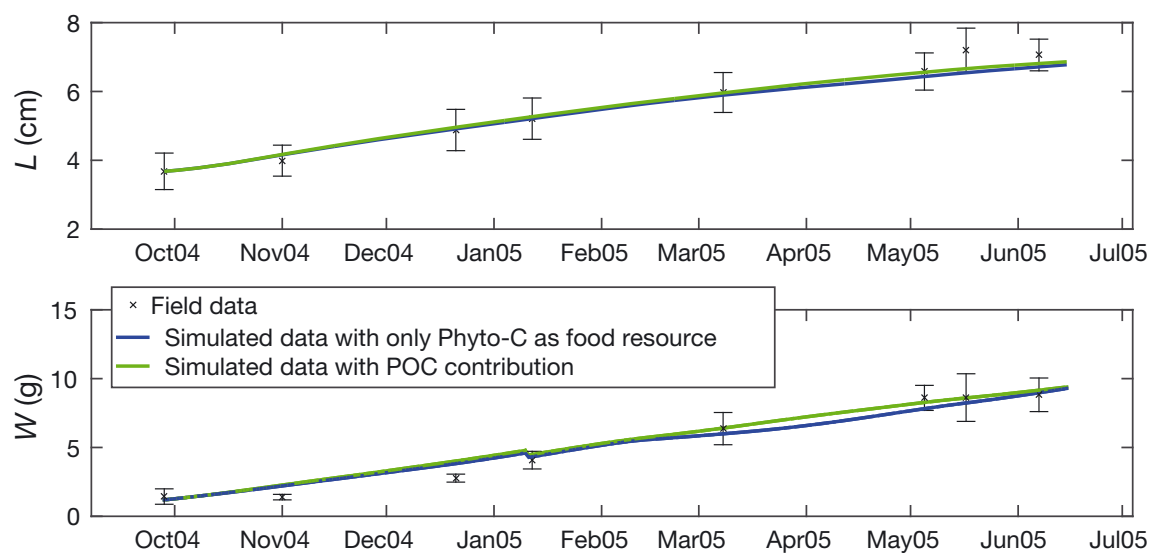

Fig. 3. Simulated mussel shell length $(L)$ (top) and fresh tissue mass $(W)$ against Maliakos data (mean $\pm \mathrm{SD}$ ), using phytoplankton carbon biomass (Phyto-C) $(X=$ $[$ Phyto-C]; blue line) and both Phyto-C and particulate organic carbon (POC) (Eq. 12; green line) in the mussel diet
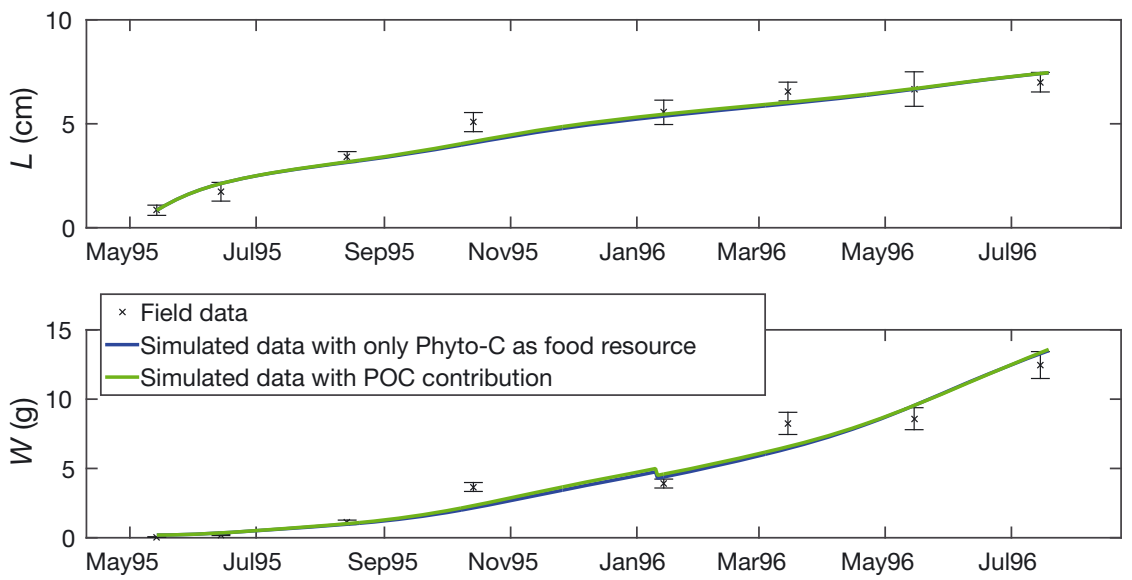

Fig. 4. Simulated mussel shell length $(L)$ (top) and fresh tissue mass $(W)$ against Thermaikos data (mean $\pm \mathrm{SD}$ ), using phytoplankton carbon biomass (Phyto-C) $(X=[$ Phyto-C $]$; blue line) and both Phyto-C and particulate organic carbon (POC) (Eq. 12; green line) in the mussel diet

values for the 2 areas: $X_{\mathrm{k}}=36 \mathrm{mg} \mathrm{C} \mathrm{m}{ }^{-3}$ for Maliakos Gulf and $X_{\mathrm{k}}=28 \mathrm{mg} \mathrm{C} \mathrm{m}^{-3}$ for Thermaikos Gulf; $X_{\mathrm{k}}$ not only depends on species but is also site-specific (Troost et al. 2010). The different values of $X_{\mathrm{k}}(36 \mathrm{mg}$ $\mathrm{C} \mathrm{m}^{-3}$ or $0.72 \mu \mathrm{g} \mathrm{chl} \mathrm{a} \mathrm{l}^{-1}$ at Maliakos and $28 \mathrm{mg} \mathrm{C} \mathrm{m}^{-3}$

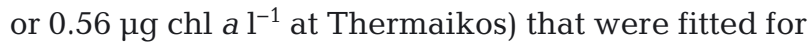
the 2 study areas can be attributed to differences in Phyto-C variability between the 2 environments (see 'Environmental data' above). These fitted values of $X_{\mathrm{k}}$ were, as expected, slightly lower compared to those found in more productive areas. Casas \& Bacher (2006) found $X_{\mathrm{k}}=3.88 \mu \mathrm{g} \mathrm{l}^{-1}\left(\sim 194 \mathrm{mg} \mathrm{C} \mathrm{m}^{-3}\right)$ on the French Mediterranean shoreline, while Troost et al. (2010) found $X_{\mathrm{k}}=2.23 \mu \mathrm{g} \mathrm{l}^{-1}\left(\sim 116.5 \mathrm{mg} \mathrm{C} \mathrm{m}^{-3}\right)$ in southwest Netherlands.
To achieve a more realistic simulation of mussel growth, POC was added to the diet of $M$. galloprovincialis, with food function, $X$, given by Eq. (12). In Figs. $3 \& 4$, the results can be compared with those obtained with food density $X=$ [Phyto-C]. At Maliakos Gulf, including $\mathrm{POC}$ in the diet resulted in a better fit between simulated and field data. This area is characterized by low Phyto-C concentrations from the middle of February until late April. During this period, POC values are higher relative to Phyto-C and this appears to significantly contribute to mussel growth. On the other hand, POC appears to have no significant role in the $M$. galloprovincialis diet at Thermaikos Gulf, as in this area Phyto-C is characterized by much weaker variability, with POC concentrations always lower than Phyto-C.

\section{Comparison between field and simulated data: model performance}

As a useful index of the model skill, simulated mussel growth was plotted against field data in Figs. 5 \& 6. Points along the $x=y$ line indicate a perfect fit. In most occasions, points are very close to that line. Moreover, the model bias and unbiased root-mean-square-deviation (RMSD) against field data were calculated and plotted on target diagrams (Jolliff et al. 2009) in Figs. $7 \& 8$. The marks are very close to the center of the diagram, indicating a successful simulation. The mean model bias, indicated on the $y$-axis, shows that referring to the overall mean value, the simulated shell length is slightly overestimated $(y>$ 0 ), while the fresh mass tissue is slightly underestimated $(y<0)$ at Maliakos Gulf and in a very good agreement with field data at Thermaikos Gulf $(y \sim$ $0)$. Additionally, the unbiased RMSD suggests that the standard deviation of the model is larger $(x>0)$ except for the fresh mass tissue at Thermaikos Gulf $(x<0)$. 

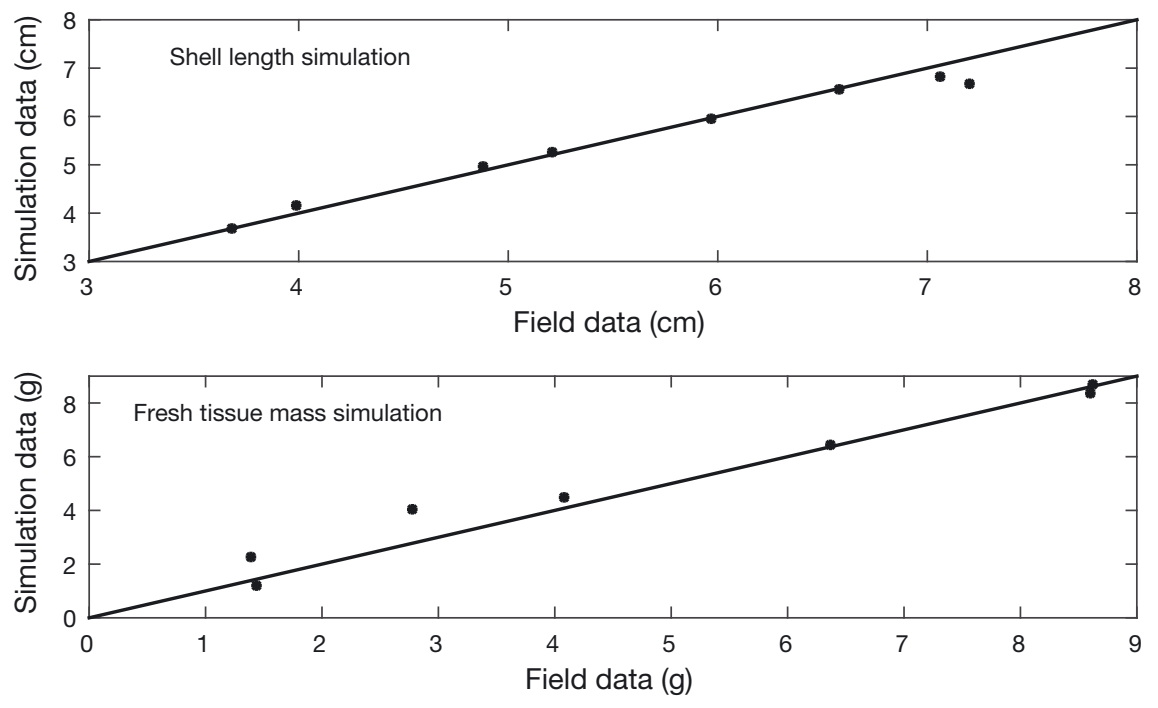

Fig. 5. Field data against simulation data (stars) at Maliakos Gulf plotted against a $y=x$ line

\section{Model uncertainty and ensemble forecasting}

The initial values of $E$ and $R$ and the values of the calibrated parameters $\left(X_{\mathrm{k}}, a_{\mathrm{f}}, b_{\mathrm{f}}\right)$ may be considered relatively unknown. To examine the model's sensitivity relative to the uncertainty of initialization/ calibration, a series of sensitivity simulations were performed, adopting a representative envelope of 5 different values (Table 5) for each initial value and calibrated parameter, with the exception of the preference coefficients $a_{f}$ and $b_{f}$, which did not show a significant sensitivity in preliminary tests. $X_{\mathrm{k}}$ was perturbed by 15 and $30 \%$ of its standard value, while initial $E$ and $R$, to which the model shows less sen-
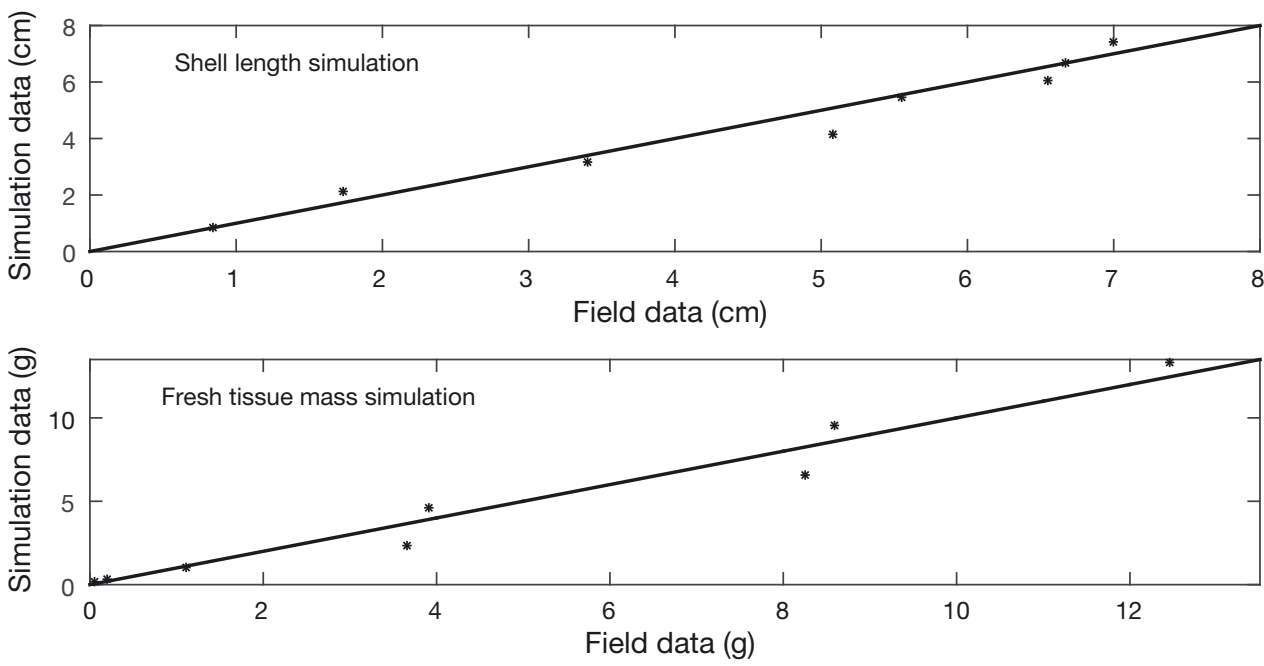

Fig. 6. Field data against simulation data (stars) at Thermaikos Gulf plotted against a $y=x$ line sitivity (Bacher \& Gangnery 2006), were perturbed by 50 and $100 \%$. In the Thermaikos Gulf simulation, where initial $R$ was set at zero, 5 values from 0 to $100 \mathrm{~J}$ were adopted. Model runs were executed with each possible combination of the 3 parameter values, giving a total of 125 runs. The mean and standard deviation from all model results were then calculated, as shown in Figs. $9 \& 10$ for the Maliakos and Thermaikos study cases, respectively. Araújo \& New (2007) demonstrated the advantages of an ensemble forecasting in biological models. Instead of selecting the best tuning values, a better procedure is to present a range of possible model states within an envelope concerning the representative parameterization/initialization values.

The uncertainty of the model, as represented by the standard deviation, appears to increase as the mussel grows, particularly regarding its wet weight. This does not indicate a decrease in the model skill, as a similar increase of standard deviation with growing mussels was also found in the wet weight field data, considering that each individual of the farm may grow in a different way, ultimately reaching a different final weight. This does not apply to the shell length evolution, which seems to be a more standard process. It is also noticeable that a weakness of the model is in efficiently simulating the individual's production of fresh tissue mass during the period before spawning (from early November 2004 to early January 2005 for Maliakos, and during October 1995 for Thermaikos Gulf). This could imply errors in the simulated reproduction of the individual that are either related to the adopted spawning day/ period or to the assumed weight loss due to spawning. According to Van Haren et al. (1994), mussels lose 40 to $70 \%$ of their wet weight during spawning. This does not occur in the presented simulations, where weight loss is around $10 \%$. However, if the 


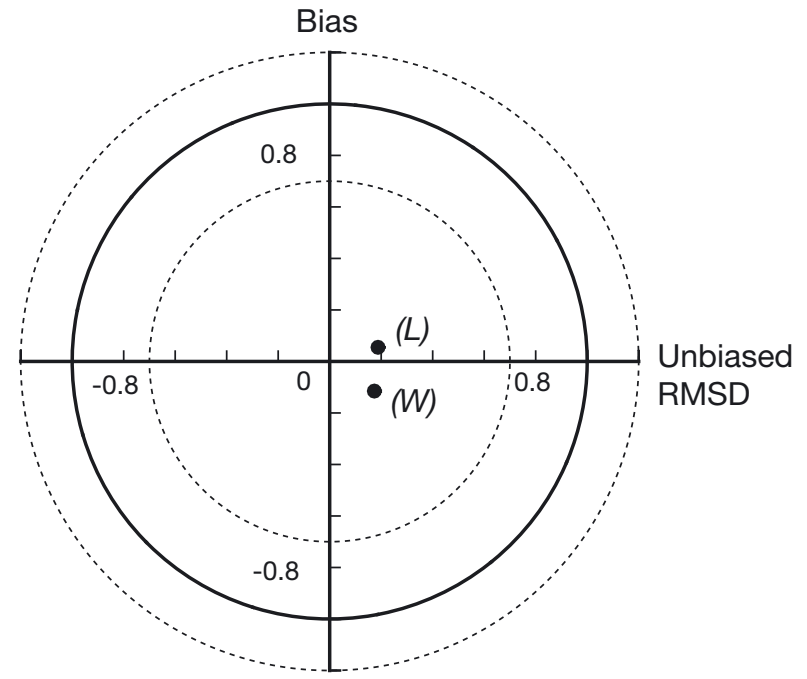

Fig. 7. Target diagram of simulated shell length $(L)$ and fresh mass tissue weight $(W)$ against field data from the Maliakos Gulf. The model bias is indicated on the $y$-axis while the unbiased root-mean-square-deviation (RMSD) is indicated on the $x$-axis

simulation continues for a second or a third year, the percentage of wet weight loss increases to $20 \%$ on subsequent spawning events.

\section{DISCUSSION}

A DEB model was developed and tuned against data from Maliakos and Thermaikos Gulfs to study the growth of cultured mussel Mytilus galloprovincialis.

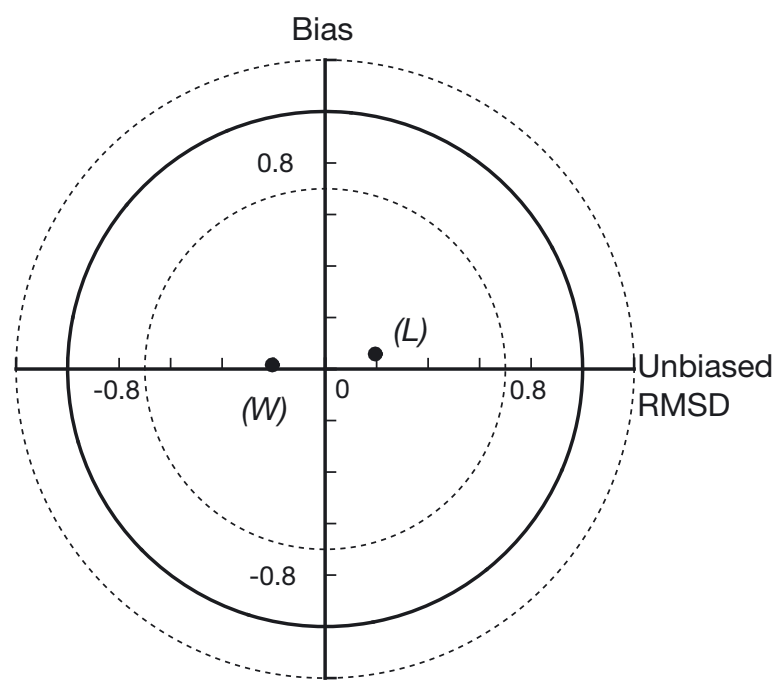

Fig. 8. Target diagram of simulated shell length $(L)$ and fresh mass tissue weight $(W)$ against field data from the Thermaikos Gulf. The model bias is indicated on the $y$-axis while the unbiased root-mean-square deviation (RMSD) is indicated on the $x$-axis
The 2 environments showed differences mostly in terms of Phyto-C and POC fluctuations and maximum values, which has an impact on the diet of M. galloprovincialis. At first, model simulations were performed accounting for only Phyto-C as a food resource for the mussel. In a second approach, available food density was modified to also include POC, aiming to investigate the contribution of $\mathrm{POC}$ to mussel growth. In this case, following the available literature, it was assumed that $M$. galloprovincialis assimilates POC only when the density of Phyto-C is not enough for its needs. This was formulated, adopting different preference coefficients for Phyto-C $\left(a_{\mathrm{f}}=0.55\right)$ and POC $\left(b_{\mathrm{f}}=0.45\right)$ in the mussel food density (Eq. 12). The results showed a small contribution of POC at Maliakos Gulf and almost none at Thermaikos Gulf. This is in agreement with Troost et al. (2010), who found a site-dependent contribution of detritus. The values of $a_{\mathrm{f}}$ and $b_{\mathrm{f}}$ could be parameterized in a way that would allow POC to have a more significant role in the mussel growth. Simulations with higher $b_{\mathrm{f}}$ (0.55 to 0.8$)$ and lower $a_{\mathrm{f}}(0.45$ to 0.2$)$, combined with higher values of $X_{\mathrm{k}}$, showed that the model could produce similar results to those presented; however, this would be in conflict with most of the literature, where phytoplankton is considered the principal food source for mussels (Williams 1981, Langdon \& Newell 1990, Garen et al. 2004). In general, the simulations are satisfactory when considering only Phyto-C as available food for the mussel. Under this assumption, the model is simplified, with $X_{\mathrm{k}}$ being the only parameter that has to be tuned. However, the model appears more stable when POC is included in the mussel's diet.

The 2 study areas are very similar with regard to sea surface temperature, and thus differences in the

Table 5. Parameter values used for the estimation of model uncertainty. Bold numbers are the standard values of initial energy reserves $(E)$, initial energy allocated to development and reproduction $(R)$ and half saturation coefficient $\left(X_{\mathrm{k}}\right)$

\begin{tabular}{|lcc|}
\hline Initial $E(\mathrm{~J})$ & Initial $R(\mathrm{~J})$ & $X_{\mathrm{k}}\left(\mathrm{mg} \mathrm{C} \mathrm{m}^{-3}\right)$ \\
\hline Maliakos Gulf & & \\
0 & 0 & 25.2 \\
350 & 150 & 30.6 \\
$\mathbf{7 0 0}$ & $\mathbf{3 0 0}$ & $\mathbf{3 6}$ \\
1050 & 450 & 41.4 \\
1400 & 600 & 46.8 \\
Thermaikos Gulf & & \\
0 & $\mathbf{0}$ & 19.6 \\
175 & 20 & 23.8 \\
$\mathbf{3 5 0}$ & 50 & $\mathbf{2 8}$ \\
500 & 80 & 32.2 \\
700 & 100 & 36.4 \\
\hline
\end{tabular}



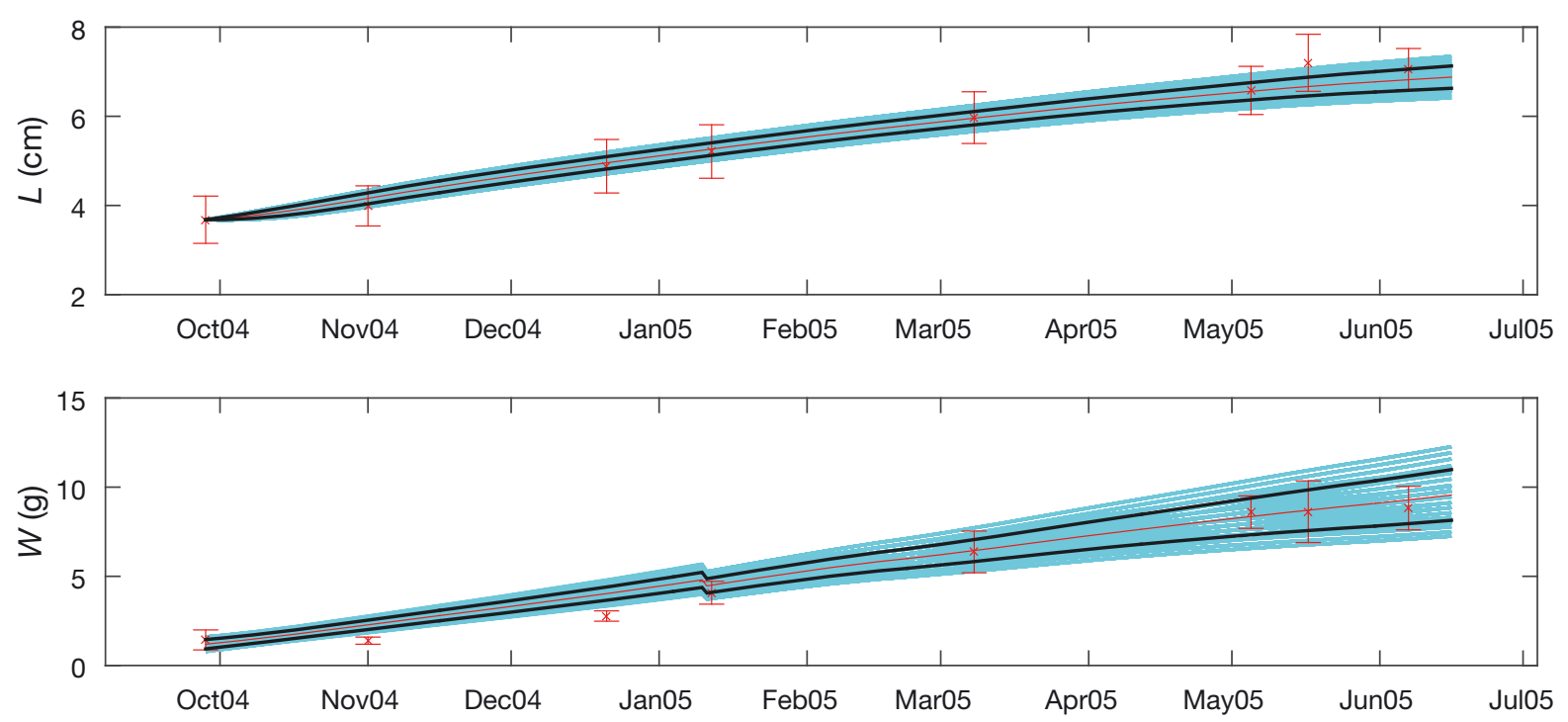

Fig. 9. Model uncertainty for the Maliakos simulation. Blue lines: the 125 model runs with each possible combination among the perturbed values of the initial energy reserves $(E)$, reproductive buffer $(R)$ and half-saturation coefficient $\left(X_{\mathrm{k}}\right)$ given in

Table 5. Red line: computed mean value; black lines: \pm SD. Red crosses and bars are for field data $(m e a n \pm S D)$
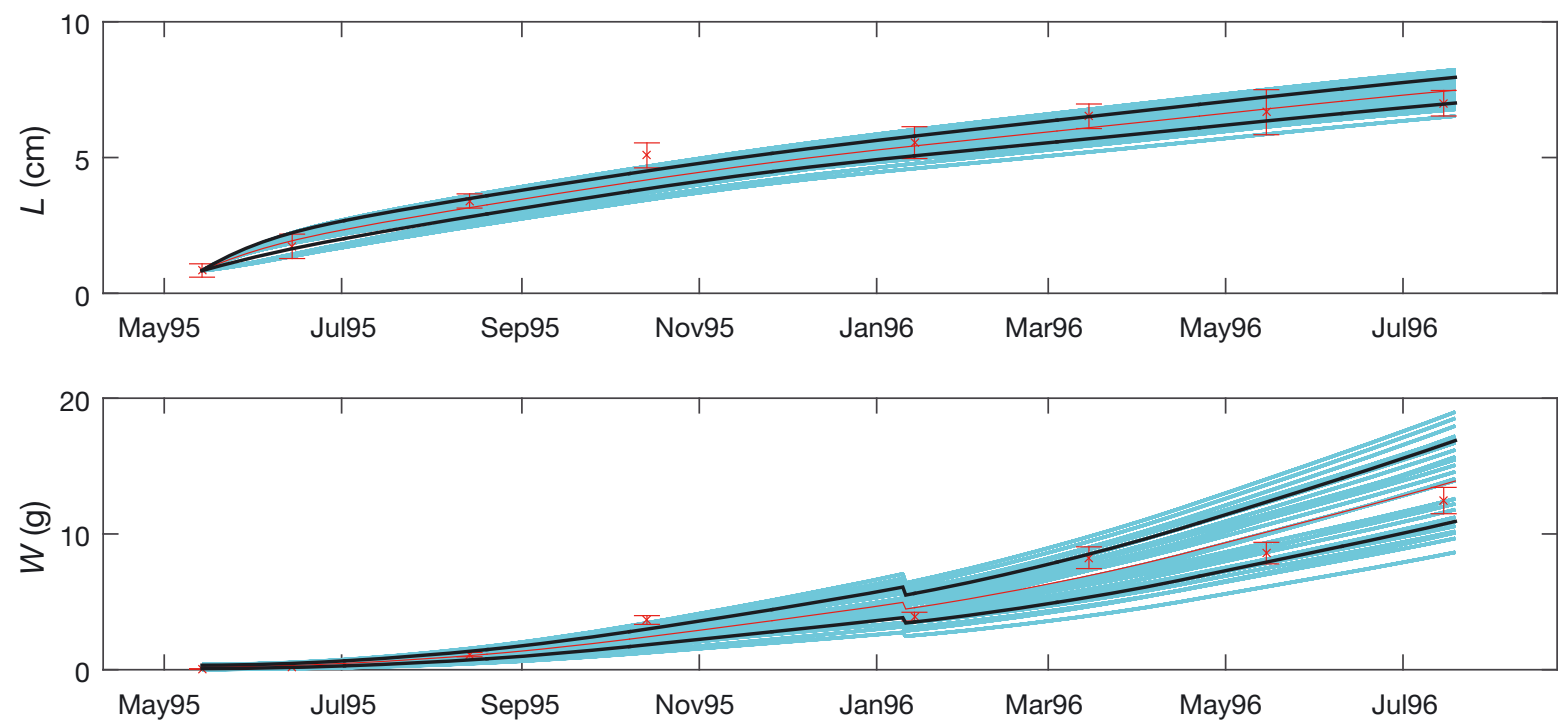

Fig. 10. Model uncertainty for the Thermaikos simulation. Blue lines: the 125 model runs with each possible combination among the perturbed values of initial energy reserves $(E)$, reproductive buffer $(R)$ and half saturation coefficient $\left(X_{\mathrm{k}}\right)$ given in

Table 5. Red line: computed mean value; black lines: \pm SD. Red crosses and bars are for field data $(\mathrm{mean} \pm \mathrm{SD})$

growth of cultured mussels may be attributed only to differences in food resources. Temperature affects the growth of the simulated mussel through the temperature dependence $k(T)$, which is multiplied by each physiological rate (i.e. $\left.\dot{p}_{a,} \dot{p}_{c,}\left[\dot{p}_{M}\right]\right)$. Increasing the temperature time series by $1^{\circ} \mathrm{C}$ in the Maliakos Gulf simulation resulted in an increase of $0.86 \%$ for final shell length and $2.83 \%$ for final fresh mass tissue. Although this response to temperature does not seem significant for the purpose of the present study, it could be interesting in the con- text of a climate change scenario investigating the effect of global warming on Aegean Sea mussel farms.

To quantify the uncertainty related to the fitted model parameters (initial values of $E$ and $R$ and $X_{\mathrm{k}}$ ), different values of these parameters were tested and a series of simulations was performed with all possible combinations, leading to a representation of the DEB model uncertainty. The results showed that in most cases, the uncertainty related to the different simulations is within the limits of the field data stan- 
dard deviation, suggesting that small perturbations to the calibrated values of $E, R$ and $X_{\mathrm{k}}$ do not have a strong influence on model outputs and thus the model remains valid.

In general, the model performed well in simulating the growth of the cultured mussel M. galloprovincialis. While the simulation of shell length growth was satisfactory, the agreement between observed and simulated weights was not as good, suggesting that there is a need for optimization of parameters related to the weight-length relations, such as the energy content of reserves $\left(\mu_{\mathrm{E}}\right)$ and the shape coefficient $\left(\delta_{\mathrm{m}}\right)$, for which many different estimates can be found in the literature (Casas \& Bacher 2006, Van der Veer et al. 2006, Thomas et al. 2011, Sarà et al. 2012). In the present study, the best fit with the field data was obtained with parameter values adopted from Casas \& Bacher (2006). Representation of model uncertainty due to initial $E_{1} R$ and $X_{\mathrm{k}}$ led to a more reliable simulation, as in most occasions there is no easy way to estimate those parameters with satisfactory accuracy. More work in this direction needs to be done in the future, as there is still room for optimization of the DEB parameters. In his work on the estimation of DEB parameters for bivalve species, Van der Veer et al. (2006) concluded that there was a standard error of about $30 \%$ on his estimates. Different values can be found among different studies on the same species; i.e. Troost et al. (2010) and Thomas et al. (2011) used a fraction of utilized energy spent on maintenance/growth $\kappa=0.45$ for $M$. edulis, while Picoche et al. (2014) used $\kappa=0.67$. Other relevant examples involve $\delta_{\mathrm{m}}$ and $\left\{\dot{p}_{A \mathrm{~m}}\right\}_{;}$Sarà et al. (2012) and Rinaldi et al. (2014) used $\delta_{\mathrm{m}}=0.2254$ and $\left\{\dot{p}_{A \mathrm{~m}}\right\}=$ $173.184 \mathrm{~J} \mathrm{~cm}^{-2} \mathrm{~d}^{-1}\left(=7.216 \mathrm{~J} \mathrm{~cm}^{-2} \mathrm{~h}^{-1}\right)$ for M. galloprovincialis, while Casas \& Bacher (2006) and Zaldí$\operatorname{var}(2008)$ used $\delta_{\mathrm{m}}=0.25$ and $\left\{\dot{p}_{A \mathrm{~m}}\right\}=147.6 \mathrm{~J} \mathrm{~cm}^{-2} \mathrm{~d}^{-1}$, which worked better with the presented data. Building an envelope of a targeted set of the most sensitive model parameters with different values found in the literature (such as $\kappa, \delta_{\mathrm{m}}$ and $\left\{\dot{p}_{A \mathrm{~m}}\right\}$ ) could lead to more reliable and general ensemble simulations, and also provide an estimate of the model uncertainty related to these parameters. This could be strengthened by including in the ensemble other bio-energetic individual models (such as a SFG model; Brigolin et al. 2009 among others). Furthermore, a full description of the model uncertainties should include uncertainty due to environmental forcing, along with uncertainties due to parameterization and initialization. This complete representation of a DEB model uncertainties could lead to a better understanding of the model dynamics. Additionally, ensemble forecasting (Araújo
\& New 2007) in the DEB model could be used to apply climate change scenarios and investigate climate change effects on species.

Although the model worked well at the 2 specific study areas and ensemble forecasting provided a quantification of uncertainties due to parameters and initial value calibrations, the model still suffers from some limitations. In the present study, the simulated individual is considered to be representative of the mussel farm's mean state. However, one should also take into account the farm's population effect. Generally, in a predator-prey system the rate of an individual's consumption is affected by the density of predators (Kratina et al. 2009). Kratina et al. (2009) tested different functional responses, concluding that those taking into account predator density provide better results. In the context of the present study, one way to take into account the effect of the farm's population on individual mussel growth with the DEB model would be to modify the Hollings Type II functional response function $(f)$, expressing $X$ and $X_{\mathrm{k}}$ in terms of food resources per mussel density. This approach could be tested in future work.

Another simplification that can be regarded as a limitation of the model is the assumption that $M$. galloprovincialis filtrates phytoplankton and POC of every size. Many studies emphasize the selectivity of Mytilus spp. with respect to size and species of phytoplankton (Bayne et al. 1987, Raby et al. 1997 among others). Other studies (Lehane \& Davenport 2006, Prato et al. 2010, Ezgeta-Bali et al. 2012) suggest that Mytilus spp. can consume even zooplankton in certain periods and areas. Therefore, in order to have a detailed description of mussel diet, food density $X$ should consist of each proxy food (different size groups of phytoplankton and POC) separately adjusted by a suitable preference weight; an effort that should be supported by field data diet analyses. On the other hand, such a model would be more difficult to tune, and uncertainties due to parameter calibration would be higher.

Due to its generic character, the model developed in the present study can easily be adapted to simulate the growth of other bivalve species, such as native oysters Ostrea edulis and European clams Tapes decussatus, with potential farming interest in Greek coastal waters.

Acknowledgements. The authors thank George Verriopoulos, professor of marine biology at the University of Athens for his helpful advice on biological matters. Data provided for Maliakos are outcomes of the Project ARCHIMIDES I -EPEAEK II-EU funded (contract no 10012-00004) 'Environmental Interactions of the Mussel farming' (2004-2007). 


\section{LITERATURE CITED}

Araújo MB, New M (2007) Ensemble forecasting of species distributions. Trends Ecol Evol 22:42-47

Bacher C, Gangnery A (2006) Use of dynamic energy budget and individual based models to simulate the dynamics of cultivated oyster populations. J Sea Res 56: 140-155

Baretta JW, Ebenhoh W, Ruardij P (1995) The European regional seas ecosystem model, a complex marine ecosystem model. Neth J Sea Res 33:233-246

Bayne B, Hawkins A, Navarro E (1987) Feeding and digestion by the mussel Mytilus edulis L. (Bivalvia: Mollusca) in mixtures of silt and algal cells at low concentrations. J Exp Mar Biol Ecol 111:1-22

Blumberg AF, Mellor GL (1983) Diagnostic and prognostic numerical circulation studies of the South Atlantic Bight. J Geophys Res 88:4579-4592

Bourlès Y, Alunno-Bruscia M, Pouvreau S, Tollu G and others (2009) Modelling growth and reproduction of the Pacific oyster Crassostrea gigas: advances in the oysterDEB model through application to a coastal pond. J Sea Res 62:62-71

Brigolin D, Maschio G, Rampazzo F, Giani M, Pastres R (2009) An individual-based population dynamic model for estimating biomass yield and nutrient fluxes through an off-shore mussel (Mytilus galloprovincialis) farm. Estuar Coast Shelf Sci 82:365-376

Camacho A, Labarta U, Beiras R (1995) Growth of mussels (Mytilus edulis galloprovincialis) on cultivation rafts: influence of seed source, cultivation site and phytoplankton availability. Aquaculture 138:349-362

Casas S, Bacher C (2006) Modelling trace metal (Hg and Pb) bioaccumulation in the Mediterranean mussel, Mytilus galloprovincialis, applied to environmental monitoring. J Sea Res 56:168-181

Christou ED, Pagou K, Christianidis S, Papathanassiou E (1995) Temporal and spatial variability of plankton communities in a shallow embayment of the Eastern Mediterranean. In: Eleftheriou A, Ansell AD, Smith CJ (eds) Biology and ecology of shallow coastal waters. Olsen and Olsen, Fredensborg, p 3-10

Dimitriou PD, Karakassis I, Pitta P, Tsagaraki TM and others (2015) Effects of mussel farming on quality indicators of the marine environment: good benthic below poor pelagic ecological status. Mar Pollut Bull 101:784-793

Eurostat (2016) Eurostat. http://ec.europa.eu/eurostat (accessed 12 Sep 2016)

Ezgeta-Bali D, Najdek M, Peharda M, Blažina M (2012) Seasonal fatty acid profile analysis to trace origin of food sources of four commercially important bivalves. Aquaculture 334-337:89-100

FAO (Food and Agriculture Organization of the United Nations) (2016) The state of world fisheries and aquaculture 2016. Contributing to food security and nutrition for all. FAO, Rome

Fasoulas TA, Fantidou ES (2008) Spat dynamic pattern of cultured mussel Mytilus galloprovincialis (Lamarck, 1819) in NW Gulf of Thessaloniki. Abstract presented at the $4^{\text {th }}$ International Congress on Aquaculture, Fisheries Technology and Environmental Management, November 21-22, 2008, Athens, Greece

FGM (Federation of Greek Maricultures) (2015) The Greek aquaculture. Federation of Greek Maricultures, Athens

Fly EK, Hilbish TJ (2013) Physiological energetics and bio- geographic range limits of three congeneric mussel species. Oecologia 172:35-46

* Garen P, Robert S, Bougrier S (2004) Comparison of growth of mussel, Mytilus edulis, on longline, pole and bottom culture sites in the Pertuis Breton, France. Aquaculture 232:511-524

* Geider J, Piatt T (1986) A mechanistic model of photoadaptation in microalgae. Mar Ecol Prog Ser 30:85-92

Gosling EM (1984) The systematic status of Mytilus galloprovincialis in western Europe: a review. Malacologia 25:551-568

Handa A, Alver M, Edvardsen C, Halstensen S and others (2011) Growth of farmed blue mussels (Mytilus edulis L.) in a Norwegian coastal area; comparison of food proxies by DEB modeling. J Sea Res 66:297-307

Hilbish TJ, Bayne BL, Day A (1994) Genetics of physiological differentiation within the marine mussel genus Mytilus. Evolution 48:267-286

Holling C (1959) Some characteristics of simple types of predation and parasitism. Can Entomol 91:385-398

Jolliff J, Kindle J, Shulman I, Penta B, Friedrichs M, Helber R, Arnone R (2009) Summary diagrams for coupled hydrodynamic-ecosystem model skill assessment. J Mar Syst 76:64-82

Kakali F, Vildou I, Theodorou JA, Tzovenis I, Rizos D, Kagalou I (2006) Trophic state evaluation of Maliakos bay (Greece), for potential development of the mussel Mytilus galloprovincialis farming. Abstract presented at Aqua2006: annual meeting of the World Aquaculture Society, 9-13 May 2006, Florence, Italy

Konstantinou Z, Kombiadou K, Krestenitis Y (2015) Effective mussel-farming governance in Greece: testing the guidelines through models, to evaluate sustainable management alternatives. Ocean Coast Manage 118: $247-258$

Kooijman SALM (1986) Energy budgets can explain body size relations. J Theor Biol 121:269-282

Kooijman S (2000) Dynamic energy and mass budgets in biological systems. Cambridge University Press, Cambridge

Kormas KA, Kapiris K, Thessalou-Legaki M, Nicolaidou A (1998) Quantitative relationships between phytoplankton, bacteria and protists in an Aegean semi-enclosed embayment (Maliakos Gulf, Greece). Aquat Microb Ecol 15:255-264

Kormas K, Garametsi V, Nicolaidou A (2002) Size-fractionated phytoplankton chlorophyll in an Eastern Mediterranean coastal system (Maliakos Gulf, Greece). Helgol Mar Res 56:125-133

Kratina P, Vos M, Bateman A, Anholt B (2009) Functional responses modified by predator density. Oecologia 159: 425-433

Kravva N (2000) Genetic composition and growth in Mytilus galloprovincialis populations in the Thermaikos Gulf. $\mathrm{PhD}$ dissertation, Aristotle University of Thessaloniki

*Langdon CJ, Newell RIE (1990) Utilization of detritus and bacteria as food sources by two bivalve suspension-feeders, the oyster Crassostrea virginica and the mussel Geukensia demissa. Mar Ecol Prog Ser 58:299-310

* Larsen P, Filgueira R, Riisgård H (2014) Somatic growth of mussels Mytilus edulis in field studies compared to predictions using BEG, DEB, and SFG models. J Sea Res 88: 100-108

Kehane C, Davenport J (2006) A 15-month study of zooplankton ingestion by farmed mussels (Mytilus edulis) 
in Bantry Bay, Southwest Ireland. Estuar Coast Shelf Sci 67:645-652

Malone T, Chervin M (1979) The production and fate of phytoplankton size fractions in the plume of the Hudson River, New York Bight. Limnol Oceanogr 24:683-696

Pagou K (2005) Eutrophication in Hellenic coastal areas. In: Papathnasiou E, Zenetos A (eds) State of the Hellenic marine environment. Hellenic Centre for Marine Research (HCMR), Anavissos, p 311-317

Papakonstantinou C, Zenetos A, Vassilopoulou V, Tserpes G (2007) State of Hellenic fisheries. Hellenic Centre for Marine Research, Institute of Marine Biological Resources, Athens

Picoche C, Le Gendre R, Flye-Sainte-Marie J, Françoise S, Maheux F, Simon B, Gangnery A (2014) Towards the determination of Mytilus edulis food preferences using the dynamic energy budget (DEB) theory. PLOS ONE 9: e109796

P Pouvreau S, Bourlès Y, Lefebvre S, Gangnery A, AlunnoBruscia M (2006) Application of a dynamic energy budget model to the Pacific oyster, Crassostrea gigas, reared under various environmental conditions. J Sea Res 56:156-167

Prato E, Portacci G, Biandolino F (2010) Effect of diet on growth performance, feed efficiency and nutritional composition of Octopus vulgaris. Aquaculture 309:203-211

* Price N, Karageorgis A, Kaberi H, Zeri C and others (2005) Temporal and spatial variations in the geochemistry of major and minor particulate and selected dissolved elements of Thermaikos Gulf, Northwestern Aegean Sea. Cont Shelf Res 25:2428-2455

Kaby D, Mingelbier M, Dodson J, Klein B, Lagadeuc Y, Legendre L (1997) Food-particle size and selection by bivalve larvae in a temperate embayment. Mar Biol 127: 665-672

Rinaldi A, Montalto V, Manganaro A, Mazzola A, Mirto S, Sanfilippo M, Sarà G (2014) Predictive mechanistic bioenergetics to model habitat suitability of shellfish culture in coastal lakes. Estuar Coast Shelf Sci 144:89-98

* Rodrigues LC, van den Bergh JCJM, Massa F, Theodorou JA, Ziveri P, Gazeau F (2015) Sensitivity of Mediterranean bivalve mollusc aquaculture to climate change and ocean acidification: results from a producers' survey. J Shellfish Res 34:1161-1176

* Rosland R, Strand $\varnothing$, Alunno-Bruscia M, Bacher C, Strohmeier T (2009) Applying dynamic energy budget (DEB) theory to simulate growth and bio-energetics of blue mussels under low seston conditions. J Sea Res 62: 49-61

Sarà G, Reid G, Rinaldi A, Palmeri V, Troell M, Kooijman S (2012) Growth and reproductive simulation of candidate shellfish species at fish cages in the Southern Mediterranean: dynamic energy budget (DEB) modelling for integrated multi-trophic aquaculture. Aquaculture 324-325:259-266

Theodorou JA, Nathanailidis K, Kagalou I, Rizos D, Georgiou P, Tzovenis I (2006a) Spat settlement pattern of the cultured Mediterranean mussel Mytilus galloprovincialis in the Maliakos Bay (Greece). Abstract presented at Aqua2006: annual meeting of the World Aquaculture

Editorial responsibility: Gianluca Sará,

Palermo, Italy
Society, 9-13 May 2006, Florence, Italy

Theodorou JA, Nathanailidis K, Makaritis P, Kagalou I, Negas I, Anastasopoulou G, Alexis M (2006b) Gonadal maturation of the cultured mussel Mytilus galloprovincialis in the Maliakos Bay (Greece): preliminary results. Abstract presented at Aqua2006: annual meeting of the World Aquaculture Society, 9-13 May 2006, Florence, Italy

Theodorou J, Makartis P, Tzovenis I, Fountoulaki E, Nengas I, Kagalou I (2007) Seasonal variation of the chemical composition of the farmed mussel Mytilus galloprovincialis in Maliakos Gulf. Abstract presented at $13^{\text {th }} \mathrm{Hel-}$ lenic Congress of Ichthyologists, Mytilini, Greece

Theodorou J, Viaene J, Sorgeloos P, Tzovenis I (2011) Production and marketing trends of the cultured Mediterranean mussel Mytilus galloprovincialis Lamarck 1819, in Greece. J Shellfish Res 30:859-874

Theodorou JA, Perdikaris C, Filippopoulos NG (2015a) Evolution through innovation in aquaculture: the case of the Hellenic mariculture industry (Greece). J Appl Aquacult 27:160-181

* Theodorou JA, James R, Tzovenis I, Hellio C (2015b) The recruitment of the endangered fan mussel (Pinna nobilis, Linnaeus 1758) on the ropes of a Mediterranean mussel long line farm. J Shellfish Res 34:409-414

* Thomas Y, Mazurié J, Alunno-Bruscia M, Bacher C and others (2011) Modelling spatio-temporal variability of Mytilus edulis (L.) growth by forcing a dynamic energy budget model with satellite-derived environmental data. J Sea Res 66:308-317

Troost TA, Wijsman JWM, Saraiva S, Freitas V (2010) Modelling shellfish growth with dynamic energy budget models: an application for cockles and mussels in the Oosterschelde (southwest Netherlands). Philos Trans R Soc Lond B Biol Sci 365:3567-3577

Tsiaras K, Petihakis G, Kourafalou V, Triantafyllou G (2014) Impact of the river nutrient load variability on the North Aegean ecosystem functioning over the last decades. J Sea Res 86:97-109

*Van der Veer HW, Cardoso JFMF, van der Meer J (2006) The estimation of DEB parameters for various Northeast Atlantic bivalve species. J Sea Res 56:107-124

*Van Haren RJF, Schepers HE, Kooijman SALM (1994) Dynamic energy budgets affect kinetics of xenobiotics in the marine mussel Mytilus edulis. Chemosphere 29: 163-189

Widdows J, Donkin P, Salkeld PN, Cleary JJ, Lowe DM, Evans SV, Thomson PE (1984) Relative importance of environmental factors in determining physiological differences between two populations of mussels (Mytilus edulis). Mar Ecol Prog Ser 17:33-47

Wijsman J, Smaal A (2011) Growth of cockles (Cerastoderma edule) in the Oosterschelde described by a dynamic energy budget model. J Sea Res 66:372-380

*Williams P (1981) Detritus utilization by Mytilus edulis. Estuar Coast Shelf Sci 12:739-746

Zaldívar J (2008) A general bioaccumulation DEB model for mussels. JRC Scientific and Technical Reports. European Commission, Institute for Health and Consumer Protection, Joint Research Centre (JSR), Luxembourg

Submitted: November 24, 2016; Accepted: June 26, 2017

Proofs received from author(s): September 5, 2017 